\title{
24. Sabahattin Ali’nin hayatında aşkın yeri ve aşk temli şiirlerinin tem, dil ve üslup açısından incelemesi
}

\section{Yıldıray BULUT}

\begin{abstract}
APA: Bulut, Y. (2021). Sabahattin Ali’nin hayatında aşkın yeri ve aşk temli şiirlerinin tem, dil ve üslup açısından incelemesi. RumeliDE Dil ve Edebiyat Araştırmaları Dergisi, (22), 409-422. DOI: 10.29000/rumelide.886086.
\end{abstract}

\section{$\ddot{O} \mathbf{z}$}

Sabahattin Ali, (1907-1948) Cumhuriyet devri yazarlarımızdan biridir. Daha çok roman ve öyküleriyle tanınan Ali, edebiyata genç yaşında şiirle adım atmıștır. Farklı edebî türlerde eser vermiş bir yazar olarak o, tecrübelerini eserlerine aktarmıştır. Yani onun eserlerinde hayatından izler bulmak mümkündür. Hayatının büyük bir kısmı zorluklar ve sıkıntılarla geçen yazarın az olmakla beraber sosyal ve toplumsal konulu şiirleri bulunur; ancak çoğunlukla aşk, ölüm, yalnızlık ve kaçış gibi bireysel temleri tercih ettiği söylenebilir. Örneğin aşk, onun hayatındaki ve şiirlerindeki en baskın duygudur. Bu sebeple aşk temli şiirler yazması doğaldır. Öyle ki hapishane günlerini anlattığı şiirlerinin kimilerinde dahi bu duyguya yer vermiştir. Çünkü aşk, onun bu zor günlerinde yanında olan en önemli dost, destek ve güç olmuştur. Bu sayede karamsarlı̆̆ını, bedbinliğini ve umutsuzluğunu ötelemeyi hatta yenmeyi başarmış ve böylece hayatın zorluklarına karşı dayanma gücünü kendinde bulabilmiştir. O, sevinçlerini, acılarını kısacası duygularını insanlarla paylaşarak yaşamayı sever. Çoğu zaman duygularına karşılık bulamasa da aşka paylaşımcı bir açıdan yaklaşmasının sebebi budur. Bu çalışmanın kapsamını, Sabahattin Ali’nin hayatında aşkın yeri, Atilla Özkırımlı tarafından hazırlanan "Sabahattin Ali Bütün Şiirleri” adlı eserde bulunan şiirlerdeki aşk teminin, Nurullah Çetin’in “Şiir Çözümleme Yöntemi” adlı eserindeki aşk duygusuna yapılan tanımlamalara göre incelenmesi ve aşk temini içeren şiirlerin dil ve üslup özelliklerinin belirtilmesi oluşturmaktadır.

Anahtar kelimeler: Sabahattin Ali, şiir, aşk, dil, üslup

\section{The place of love in Sabahattin Ali's life and an analysis of love theme poems in terms of theme, language and style}

\begin{abstract}
Sabahattin Ali is one of our Rebuplic Period writers. Ali, mostly known with his novels and stories, started literature with poetry at an early age. As a writer who has various literary works, conveyed his experiences to his pieces. In a different word, it is possible to see signs of his life in his works. The writer, whose life was very hard and problematical, has social themed poems, although they are less, but it must be said that he prefers individual themes like love. Love is the most dominant emotion in his life and poems. For that reason, it is normal that he writes love themed poems. It is so usual that he writes about love in his some poems about his imprisonment days. Love is his the most valuable friend, support and power in those hard days. He achieved not only to postpone his pessimistic and desperate feelings but also to beat them and thus he has the power of bearing hard conditions of life. He loves sharing his joys and sorrows with people. Even though he couldn't find a
\end{abstract}

Dr. Öğr. Gör., Bartın Üniversitesi, Rektörlük, Türk Dili Bölümü (Bartın, Türkiye), yildiraybulut@hotmail.com, ORCID ID: 00oo-0003-3555-4487 [Araştırma makalesi, Makale kayıt tarihi: 11.02.2021-kabul tarihi: 20.03.2021; DOI: 10.29000/rumelide.886086].

RumeliDE Dil ve Edebiyat Araşttrmalar Dergisi Osmanağa Mahallesi, Mürver Çiçeği Sokak, No:14/8 Kadıköy - İSTANBUL / TÜRKIYE 34714 e-posta: editor@rumelide.com tel: +90 $5057958124,+902167730616$
Address

RumeliDE Journal of Language and Literature Studies

Osmană̆a Mahallesi, Mürver Çiçeği Sokak, No:14/8

Kadıköy - ISTANBUL / TURKEY 34714

e-mail: editor@rumelide.com,

phone: +90 $5057958124,+902167730616$ 


\begin{abstract}
response to his feelings, he approaches love with a sharing point of view. The scope of this study includes the place of love in Sabahattin Ali's life, the theme of love in the poems in the work titled " Sabahattin Ali Bütün Şiirleri” prepared by Atilla Özkırıml, according to the descriptions made for the feeling of love in Nurullah Çetin's work titled "Şiir Çözümleme Yöntemi". It constitutes the expressions of the language ands style features of poems.
\end{abstract}

Keywords: Sabahattin Ali, poem, love, language, style

\title{
Giriş
}

Duygular yaradılışın ayrıcalıklarıdır. Duygusu olmayan bir canlı düşünülemez. Aşk ise duygular içerisinde belki de en güçlü olanı ve hissedilenidir. Öyle ki pek çok sanatçının eserlerine ilham kaynağı olmuştur. Aşk, Türk Dil Kurumu Türkçe Sözlükte, "Aşırı sevgi ve bağlllık duygusu” (1988: 98), Osmanlıca-Türkçe Ansiklopedik Lûgat’ta "Sevgi" (Devellioğlu, 2002: 47), Kâmûs-ı Türkî'de "Sevgi, sevdâ, muhabbet, alâka, ibtilâ" (Sami, 2018: 727) ve Türkiye Diyanet Vakfi İslam Ansiklopedisi'nde, "Arapça aslı ışk olup sözlükte "şiddetli ve aşırı sevgi; bir kimsenin kendisini tamamen sevdiğine vermesi, sevgilisinden başka güzel görmeyecek kadar ona düşkün olması' anlamına gelir.” (Uludağ, 1991: 11) şeklinde tarif edilir. İmam-ı Muhammed Gazâli ise Salih Uçan tarafından tercüme edilen "Mükâşefetü'l-Kulûb (Kalplerin Keşfi)” adlı eserinde sevgi ve aşkı "'Sevgi' canlı varlığın, haz veren bir nesneye karşı meyil duymasıdır. Söz konusu meylin pekişip güçlenmesi hâline 'aşk' denir.” (Uçan, 2016: 47) diye tanımlar. Bu tanımlardan hareketle denebilir ki aşk ve arzu kavramları birbirinden bağımsız düşünülemez. Sevinç Türkmen Aksu'nun aktardığına göre "İnsan doğasının arzu olduğunu ifade eden Spinoza, arzuyu varolmaya dönük bir çaba ile ilişkilendirir." (Aksu, 2017: 287). Dolayısıyla aşk ve arzu kavramları bir insanın fiziksel ve manevî anlamda var oluşunda doğal gereksinimlerdir.

Ramazan Korkmaz, Sabahattin Ali -İnsan ve Eser- adlı çalışmasında Sabahattin Ali'nin şiirlerini bedbinlik, aşk, yalnızlık, kaçış temleri ve diğer temalar olmak üzere beşe ayırarak incelemiştir.² Diğer temalar başlı̆̆ı altında ise hürriyet, yabancılaşma ve sosyal konulu temalar yer almaktadır (Korkmaz, 1991: 292-301). Ancak Korkmaz, çalışmasında aşk temini incelerken on iki şiirin adını vermiş, bu tem ile yazılmış şiirlerin tümünden bahsetmemiş ve şiirlerle ilgili ayrıntılı açıklama yapmamıştır. 3 Ramazan Korkmaz'ın kitap halinde de yayımlanan değerli çalışması, "Sabahattin Ali"nin Hayatında Aşkın Yeri ve Aşk Temli Şïrlerinin Tem, Dil ve Üslup Açısından İncelemesi” başlıklı makaleye yol göstermiş ve konunun daha ayrıntılı bir biçimde (aşk temindeki tüm şiirleri ele alınarak) incelenmesi gerektiği sonucuna varılmıştır. Bu çalışmanın amacı, Sabahattin Ali’nin aşka yaklaşımını, şairin hayatındaki tecrübeler vesilesiyle açlklamak, onun aşk temli şiirlerinin tamamını temin ele alınışı bakımından incelemek ve bu şiirlerde şairin dil ve üslup özelliklerini belirlemektir.

\section{Sabahattin Ali'nin hayatında aşkın yeri}

Sabahattin Ali, aşkı hayatının odak noktası olarak belirlemiş bir şairimizdir. Bir nevi, aşka âşıktır denilebilir. Örneğin arkadaşı Özgen Ergin, Sabahattin Ali'yi “O, -Sabahattin Ali-” başlıklı yazısında "Nasıl söyleyim, çabucak yanan, sık sık sevdalanan bir insandı. Çok duygulu, romantik, aynı zamanda, yerinde duramayan coşkulu bir kişiliğe sahipti.” (Ergin, 2016) diyerek tanımlar. Sabahattin Ali,

Korkmaz, çalışmasında tem ve tema kelimelerini birlikte kullanmıştır. Bu sebeple konu başlıklarını belirtirken, başlıklar çalışmanın kendisinde nasıl geçiyorsa o şekilde aktarılmıştır. Nurullah Çetin ise tem kelimesi yerine izlek kelimesini tercih etmektedir.

3 Çalışmada aşk temini işleyen şiirlerden birinin ise sadece bir dizesi verilmiş, şiirin adı metinde geçmemiştir. Söz konusu şiirin adı Çocuklar Gibi, metinde verilen dize ise "Aşkım iki günlük iptilâlardı" dizesidir.

Adres $\mid$ Address

RumeliDE Dil ve Edebiyat Araşttrmaları Dergisi $\quad$ RumeliDE Journal of Language and Literature Studies Osmanağa Mahallesi, Mürver Çiçeği Sokak, No:14/8 Osmanağa Mahallesi, Mürver Çiçeği Sokak, No:14/8

Kadıköy - İSTANBUL / TÜRKIYE 34714 Kadıköy - ISTANBUL / TURKEY 34714 e-posta: editor@rumelide.com

tel: +90 505 7958124, +90 2167730616 phone: +90 505 7958124, +90 2167730616 
Mehmed Halil Sağlam’ın bilgilerine göre “Almanya'da bulunduğu dönemde Florayn Puder'e, İstanbul'da staj yaptı̆̆ dönemde Nahit Hanım'a, Konya'da öğretmenlik yaptı̆̆ dönemde öğrencisi Melahat Muhtar'a ve Muhsine adlı bir şarkıcıya âş̧k olmuştur." (Sağlam, 2020: 92). Sabahattin Ali'nin mektuplarını içeren Canım Aliye, Ruhum Filiz adlı eserde ise yazarın zaman içinde eşi Aliye Hanım'ı herkesten daha çok sevdiği ve ona gönülden bağlandığı görülmektedir. "Sabahattin Ali'nin mektuplarında tutkulu, vazgeçmeyen bir sevgili ve umutla bekleyen bir âşık tipi açıkça görülür." (Yıldız, 2017: 13). İbrahim Biricik'in aktardığına göre "Sabahattin Ali'nin aşkı samimi duygularla yaşadığına inanan Mehmet Güneş; Sabahattin Ali’nin kendi eserlerine, âşık olduğu kadınları yansıttığını söyler. Yazdığı mektupları, bu noktada aşk itirafnameleri gibidir.” (Biricik, 2017: 57). Aliye Hanım'a yazdığı bir mektupta ona "Herkeslerden Sevgili Aliye" (Ali, 2018: 11) diye hitap etmesi de hayatının aşkının Aliye Hanım olduğunu gösterir.

"Sabahattin Ali, şiirlerinin çoğunda neden aşk gibi bireysel bir temi tercih etmiştir?" sorusuna şöyle bir yanıt verilebilir: Sabahattin Ali ruhsal açıdan sorunları olan annesinden yeterince sevgi ve şefkat görememiştir. Çocukluk devresinde anne ile kurulan bağın derecesi, o insanın ilerleyen yaşlarında nasıl bir kişilik yapısı içinde olacağını belirler. Ayşe Arzu Korucu "Freudyen ve Jungiyen Yaklaşımlarla Anne Olgusu" başlıklı makalesinde annenin insan yaşamındaki önemini, "Yaşam yolculuğunda insanın ilk durağı olan anne, tüm yaşamı boyunca da bireyin psikolojisinde silinmeyecek izler bırakır." (Korucu, 2019: 134) şeklinde ifade eder. Aslıhan Aytaç ise Hece Dergisi'ndeki "Sabahattin Ali Şiirlerinde Trajik Yazgı" makalesinde şair için "Anne sevgisinden yoksun kalması yönüyle, mutsuz bir çocukluk geçiren şair, bunun bıraktığı olumsuz etkilerle hayatı boyunca ötelenmiş / dışlanmış hisseder." (Aytaç, 2018: 777) demektedir. Belki de şair, annesinden göremediği sevgi ve bağlllı̆̆ı hayatta karşılaşı̆ı̆ı kadınlarda aramaktadır. Şair, henüz on yedi yaşında dergilerde şiirler yayımlamaya başlar. Bu şiirler, onun duygularını dışa vurma şeklidir. Şiirlerinin çoğunda bireysel temleri tercih etmesinin sebebi kendisini anlatma çabası içinde olmasıdır.

Yazarın aşk temli şiirlerinde sevdiği kadınlardan uzakta oluşu, onların ilgi ve sevgilerine mazhar olamayışı birbiriyle ilintilidir. Hâl böyle olunca şiirlerindeki âşık kişi bir bedbinlik içine girer. Hayatı hayal kırıklıklarıyla doludur. Sevgili çoğu zaman âşı̆̆ı görmezden gelir, unutur veya dışlar. Âşık kimi zaman gururlu görünse de bu gururu kısa süreli olacak ve yeniden sevgiliyi yüceltmeye başlayacaktır. Çünkü sevgili, âşığa göre daha güçlüdür ve âşığın hayatının odak noktasındadır. Yani hayatın devamı için sevgiliye ihtiyaç vardır.

\section{Sabahattin Ali'nin şiirlerinde aşk temi}

Sabahattin Ali’nin şiirlerinde aşk, farklı özelliklerde kendini göstermektedir. Şair hayatında aşkın türlü hâllerini tecrübe etmiştir. Nurullah Çetin aşk duygusunu "Şiir Çözümleme Yöntemi" adlı eserinde yüzeysel aşk, şehevî ihtiras, romantik aşk ve yüceltilmiş aşk olarak dört kategoriye ayırır. Çetin’e göre bu gruplar şöyle tarif edilir:

"Yüzeysel aşk: Bu tür aşk duygusu derinlik ve kararlılık taşımaz. Uçarı âşık, samimi değildir, hafifmeşrep ve hercaîdir, gönül eğlendirmeye dayanır, çiçekten çiçeğe konan bir arı gibidir. Güzelden güzele dolaşır. Bir kadına sadık değildir. Sarsıcı aşk acıları yaşamaz. (...) Büyük ihtiraslar ve aşk acıları duymaz, yüzeysel bir çapkınlıkla yetinir." (Çetin, 2008: 60). "Şehevî ihtiras Sansüalite şiiri. Sevilen kadının cinselliğine yer veren, onunla cinsel teması isteyişi ya da bilfiil uygulayışı dillendiren, kadının cinselliğinden, bedeninden şehevî anlamda yararlanma ihtirasını işleyen metinlere denir." (Çetin, 2008: 61). Romantik aşk: Sevgiliye aşırı derecede duygusal bağlanımı ifade eden, sevgilinin güzelliğine duyulan sevgiyi abartılı bir biçimde terennüm eden, sevgiliden ayrılığa dayanamayışın sonucu olan karasevdayı, hüznü dillendiren aşk şiiri.” (Çetin, 2008: 62). "Yüceltilmiş aşk: (...) Bir şairin sevgilisini bir süre büyük bir aşkla sevmesi, sonra bir şekilde vuslata

\section{\begin{tabular}{r|l} 
Adres & Address \\
RumeliDE Dil ve Edebiyat Araşttrmalar Dergisi & RumeliDE
\end{tabular}} Osmanağa Mahallesi, Mürver Çiçeği Sokak, No:14/8 Osmanağa Mahallesi, Mürver Çiçeği Sokak, No:14/8 Kadıköy - İSTANBUL / TÜRKIYE 34714 Kadıköy - ISTANBUL / TURKEY 34714 e-posta: editor@rumelide.com tel: +90 505 7958124, +90 2167730616 phone: +90 505 7958124, +90 2167730616 
erememesi sonucu onu kendi iç dünyasında, ruhunda, kalbinde soyut bir imge olarak var kılması, imgeleminde kurduğu hayaliyle yetinmesi, bedenini arzulamaması ve visali, ona kavuşmayı talep etmemesidir." (Çetin, 2008: 63-64).

Çalışmanın bu kısmında aşk temli şiirler bu kategorilere göre tasnif edilecektir.4 Şiirler aşk kategorilerine göre tasnif edilirken kategorilerdeki şiir sayısı esas alınarak sıralama yapılmıştır.

a) Romantik aşk: Sabahattin Ali’nin çoğu şiirinde aşk, romantik aşk özelliği göstermektedir. Bu şiirlerde sevgili, âşığa acı çektirmekte ve ona kavuşma sevincini yaşatmamaktadır. Bazı şiirlerde âşık, sevgiliye kavuşamadığı için sabrını yitirir ve yaşama hevesini kaybeder. Bu hâlden kurtulmak için doğa ve doğadaki ögelerle arkadaşlık ederek derdini hafifletmeye çalışır. Bazen aşk karşısında isyanı bırakır, gururuna yenik düşer ve yalvarmaktan vazgeçer. Ancak bu vazgeçişler uzun süreli olmaz ve her zaman âşıktan daha güçlü olan sevgili, gurur savaşını kazanır.

Şaire göre aşk, bir insanın belki de en önemli yaşama amacıdır. Bu amaç uğruna katlanılan acılar; özlem, hicran gibi zor duygular aşkın cilveleridir. Sevdasız adlı şiirinde Sabahattin Ali, aşkın kıyametler koparıp fırtınalar yaratacak kadar güçlü bir duygu olduğunu belirtmektedir. Aşk, dünyadaki herkesin âdeta kaderi gibidir. Bu şiirde şairin aşk tarifini görmek mümkündür:

“Derler ki:

، "Dünyada sevdasız yaşanmamış

، "Bir kalp gösterir misin bu ateşte yanmamış?”,

، "Aşk öyle bir şeydir ki kimini sevindirir,",

، "Okşar, bahtiyar eder, gözyaşını dindirir...”,

، "Tabiatı tıpkı talih gibidir, yâr olmaz kimine de" ,

، "En samimi ateşle çırpınan bir sinede",

، "Kıyametler koparır, firtınalar yaratır,”,

، "Bazan bir demet güldür, bazan kanlı bir satır.”,

، "Lakin sevişmiyerek geçen ömür hederdir;”,

، "Dünyada âşık olmak herkese mukadderdir...” , ” (Ali, 2016: 91)

Şair Koşma adlı şiirinde ömründeki yıllar kadar aşk duygusunu tatmış; ancak kara bahtı yüzünden sevgililerini başkalarına kaptırmış bir âşıktır. Bu şiirin son dörtlüğünde şairin âşık tarifi yer almaktadır. Âşık, mutluluktan bihaber olan, yaşadığı hayattan zevk almayan bir kişidir. Çünkü âşığın hayat kaynağı sevgilidir ve sevgililer onu bırakıp başkalarına yâr olmuşlardır:

"Kimi âşık dileğine ulaşır,

Sevdiğiyle cümbüş eder, gülüşür,

Kimi benim gibi garip dolaşır,

Asıl âşık kâm almıyan kişidir.” (Ali, 2016: 56)

Şairin aşk ve âşı tarifinden sonra, âşı̆̆ın sevgiliyi nasıl gördüğü ve ona karşı neler hissettiğine bakabiliriz. Sabahattin Ali'nin zorlu ve sıkıntılı bir hayat yaşadığı bilinmektedir. Ona bu zorlu

Şairin içinde aşk veya yâr ifadesi geçmesine rağmen herhangi bir aşk kategorisinde sayllamayacak dört şiiri bulunur. Bu şiirler Dağlar, Melankoli, Nedâmet ve Gazel Naziresi adlarını taşır.

Adres $\mid$ Address

RumeliDE Dil ve Edebiyat Araşttrmaları Dergisi $\quad$ RumeliDE Journal of Language and Literature Studies Osmanağa Mahallesi, Mürver Çiçeği Sokak, No:14/8 Osmanağa Mahallesi, Mürver Çiçeği Sokak, No:14/8

Kadıköy - İSTANBUL / TÜRKIYE 34714 Kadıköy - ISTANBUL / TURKEY 34714 e-posta: editor@rumelide.com

e-mail: editor@rumelide.com,

tel: +90 505 7958124, +90 2167730616 phone: +90 505 7958124, +90 2167730616 
hayatında güç veren yine sevgili ve sevgiliye duyduğu aşk olacaktır. Şair Öyle Günler Gördüm ki adlı şiirinde yaşadığı zor hayat nedeniyle acı çeken bir kişi konumundadır. Kara bahtı yine iş başındadır. Buna rağmen ona güç veren ve "yaşa" diyen bir sevdiği vardır:

"Sen benim sevgilimsin, sevsen de sevmesen de,

Aradığım yerlere benzeyiş buldum sende.” (Ali, 2016: 62)

Hapishane Şarkısı IV adlı şiirde de âşığın en büyük hayat kaynağının sevgili olduğu görülmektedir. Sevgili, âşığın karanlık günlerinde yolunu aydınlatan, onun hayata olan inancını pekiştiren, onu yalnızlıktan kurtaran en güvendiği kişidir:

"Karanlık göklerde aysın,

Kurak ovalarda çaysın,

Bir tek inandığım şeysin,

Uzattım sana elimi...” (Ali, 2016: 39)

Sevgiliyi yücelten ve öven âşı, onun için neredeyse yok hükmündedir. Sevgili başka yiğitlere yâr olmayı seçmiş ve âşığın aşkını karşılıksız bırakmıştır. Örneğin şairin İstanbul'da tanıştığı Nahit Hanım onu tercih etmeyerek başka biri ile evlenmiştir. Şair bu aşk uğruna gençliğini feda ettiğini Bir Macera adlı şiirinde açıklar:

"Neticesiz bir aşka verdim gençliğimi,

Ne ufak bir temayül, ne bir iltifat gördüm...

Önünde yalvararak söylerken sevdiğimi,

Gözlerinde yüzüme inen bir tokat gördüm...” (Ali, 2016: 116)

Neticesiz kalan bu aşk sonucunda şair benliğini, inançlarını ve aşka bakışını sorgulamaya başlar. Karamsar bir ruh yapısına bürünen Sabahattin Ali, amaçsız, ümitsiz ve ciddiyetsiz bir hayata doğru sürüklenmektedir. Aşka ve hayata bağlılı̆̆ını sorgulayan, Allah’tan ve insanlardan uzaklaşan şairin bu inziva hâli uzun sürmez. $\mathrm{O}$, aşkın yaşattığı acılara rağmen gönlüne söz geçiremeyen bir kişidir. Yetmez mi? adlı şiirde aşk duygusundan uzak kalamayan şairin feryadı duyulmaktadır:

"Hangi derdimi sayayım?

Aşka nasıl dayanayım?

Yandım, daha mı yanayım?

Yetmez mi gönül, yetmez mi? (Ali, 2016: 45)

Sabahattin Ali, Konya'da çalışırken Melahat Muhtar adlı öğrencisine âşık olur. Esra Yıldız'n aktardığına göre Muhtar ile aralarında dokuz yaş fark vardır (Yıldız, 2017: 16). Şair, özel mektuplarında arkadaşı Ayşe Hanım'a bu aşktan bahsetmiştir. Bir Doğum Günü Iç̧in adlı şiirinde Melahat Muhtar'a canını teslim etmeye hazırdır:

“Aşkını candan duymuşum,
Canım yoluna koymuşum.
Tam dokuz yaşındaymışım
Dünyaya geldiğin zaman.” (Ali, 2016: 53) 
Sevgili ile mutlu günler yaşamayı ve böylece aşk acısıyla dolu geçmişini unutmayı isteyen şair, hapishane günlerinin başlamasıyla bir kez daha hayal kırıklığına uğrar. Kendisini kavuşmanın mevsimi olan bahar vaktinde kırılmış bir dala benzeten Sabahattin Ali, Hapishane Şarkısı I adlı şiirde:

"Kimseye soramadığım,

Doyunca saramadığım,

Görmesem duramadı̆̆ım

Nazlı yârimden ayrıldım.” (Ali, 2016: 36)

diyerek sevgilinin hayaliyle yaşamaya devam eder. Hapishane Şarkısı II şiirinde bu durumu:

"Bakmazsa senin yüzüne

Çok görme elin kızına;

Dışarda serbest gezene

Hapiste yatan hor gelir.” (Ali, 2016: 37)

diyerek açıklamaktadır. Hapishane günlerinde şairi hayata bağlayan yegâne şey, eski sevdaları ve anılarıdır. Hapishane Şarkısı III şiirinde bu durumu şu dizelerle özetler:

“Gönülde eski sevdalar,

Gözümde dereler, bağlar,

Aynada hayalim ağlar,

Geçmiyor günler, geçmiyor.” (Ali, 2016: 38)

Sabahattin Ali, 12 Mayıs 1933'de Sinop Cezaevi'ne gönderilir (Korkmaz, 1991: 23). Ailesinden, dostlarından ve yârinden uzaklaşmıştır. Hiç kimse ziyaretine gelmemektedir. Kendini tamamen yalnız hissetmekte ve bu yalnızlık hâli içerisinde günlerini doldurmaya çalışmaktadır. Gurbet Hapishanesi şiirinin son dörtlüğünde "Yâr, beni unutma sakın" diyerek ona âdeta veda etmektedir:

"Geniş ol, göklere bakın,

Çıkacağın günler yakın...

Yâr, beni unutma sakın

Gurbet hapishanesinde.” (Ali, 2016: 41)

Servi şiirinde doğanın huzur veren, sığınılacak bir mekân olması söz konusudur. Şiirde bir servi ağacı şaire seslenmekte ve sevgilinin de bir gün burada yani servinin altında şair ile buluşacağı müjdesini vermektedir:

"Yârin de gezer dolaşır,

Bir gün buraya ulaşır;

Hasretler burda buluşur,

Rahat benim altımdadır." (Ali,2016: 32)

İstek şiirinde rüzgâr, dağ, orman, ağaç gibi doğal ögeler kendini göstermektedir. Ancak bu ögeler şairi karamsarlıktan kurtaramaz. Hatta şiirin sonunda şairin ölme isteğinde olduğu görülür:

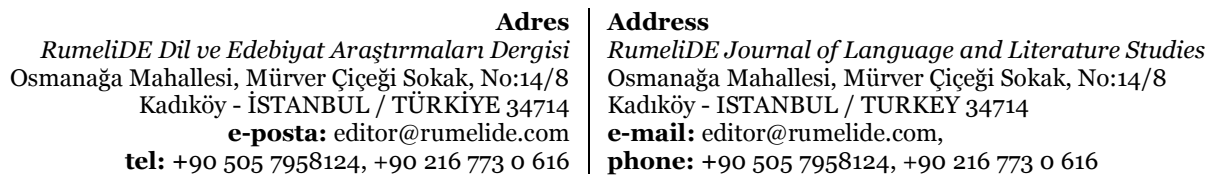


“Görünmez kollar boynumda,

Yârin hayali koynumda,

Sicak bir kurşun beynimde,

Bir ağaç dibine yatsam...” (Ali, 2016: 33)

Şair Mayıs adlı şiirinde bir mutluluk tablosu çizer. Ona göre aşk duygusu ile mayıs ayı arasında bir ilişki vardır. Bu ayda dağlar yeşillenir, her yeri kuşların sesi kaplar ve sevgili güzelliğinin doruk noktasına ulaşır:

"Yeşil dağlara göçülür,

Kızıl şaraplar içilir;

Yârim dökülüp saçllır,

Mayıs'ta gönlüm delidir." (Ali, 2016: 43)

Uzakta adlı şiirde ise ayrılığın ve özlemin verdiği etkiyle çimenler sarı renge bürünür, çiçekler solar ve âşı̆̆ın gözünden yaşlar boşanır:

"Çimenler sararıp yanmış,

Çiçekler yere kapanmış,

Yeryüzü çöllere dönmüş,

Niçin benden uzaktasın? ..” (Ali, 2016: 51)

Hey adlı şiirde şair, çektiği acılar neticesinde kendini sevgilisine sığınmış, ona sokulup divâne olmuş bir şekilde bulur. Sevgili o kadar güzeldir ki bu güzellik karşısında âşıklar ne yapacağını şaşırmaktadır. “Âşıklar sana ne yapsın?” (Ali, 2016: 44) dizesi bunun göstergesidir.

Ayırdılar şiiri bir ayrılık şiiridir. Araya giren ve türlü fesatlıklar peşinde koşan insafsız kişiler, âşı ile sevgiliyi birbirinden ayırmışıır:

"Eller araya girdiler,

Türlü fesatlar kurdular,

Sevdamızı çok gördüler

Seni benden ayırdılar." (Ali, 2016: 46)

Kıyamadığım şiiri, gurbete giden şairin geride bıraktı̆̆ı sevgilisine duyduğu özlemi anlatır. Sevgili ise o gurbette iken bir başkasını bulur:

"Evde kapanıp kaldın mı?

Seyrana çıkıp güldün mü?

Başkalarının oldun mu?

“ ‘Benimsin’” diyemediğim!” (Ali, 2016: 47)

Unutamadım şiirinde kara bahtı yüzünden sevgiliden ayrılan âşı̆ıı aşk dolu günleri hatırlaması söz konusudur. Eski mutlu günler şairin aklından bir türlü çıkmamaktadır:

"Gönlümü avutamadım,

Seni söküp atamadım,

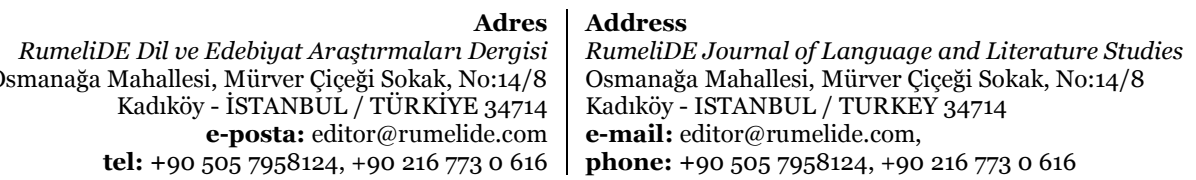


Ben bahtımı tutamadım,

Yâr, seni unutamadım.” (Ali, 2016: 48)

Ağlayı Ağlayı şiirinde sevgiliden uzak kalan şairin feryatları duyulmaktadır. Şair hayatı boyunca onca güzel görmesine rağmen sevgilinin güzelliğini hepsinden üstün tutmaktadır:

"Güzel gördüm yığın yığın,

Bel ince, gözleri baygın...

Hepsinden güzel olduğun

Bildim ağlayı ağlayı...” (Ali, 2016: 49)

Kara Yazı şiirinde sevgiliye sözü geçmeyen şairin kara bahtına olan sitemi söz konusudur. Sevgili kendisine güvenilen tek kişi olmasına ve el üstünde tutulmasına rağmen başkasına eş olmuştur:

"Yalnız ona yâr demiştik,

Onda bir şey var demiştik,

O bizi anlar demiştik,

Böyleymiş kara yazımız.” (Ali, 2016: 50)

Eskisi Gibi şiirinde Sabahattin Ali'nin sevgili ile mutlu olma hayalleri kurduğunu görmek mümkündür. Âşık ne olursa olsun, hangi acıları yaşarsa yaşasın yine sevgiliye vurgundur:

"İtilmiş, tekmelenmişim,

Doğduğum günde yanmışım,

Yalnız sana güvenmişim;

Ben gene sana vurgunum” (Ali, 2016: 52)

Son Mektup şiirinde âşı sevgilisine son bir mektup yazar ve bu mektubunda ölümün aşka engel olamayacağını belirtir:

"Şimdi yaşamayı tatlı bulursun,

Koşarsin, gülersin, tez yorulursun,

Bir gün olur yine bana gelirsin

Deli gönlün yaşamağa kandı mı...” (Ali, 2016: 57)

Kurbağanın Serenadı, tek taraflı aşkı anlatan bir şiirdir. Bu şiirde sevgili, kendisine serenad yapan âşıklara gitarlarını kırdıracak kadar aşk acısı çektiren bir zalimdir. Yosunlar arasındaki bir kurbağanın vaklaması sevgiliye yapılan bir serenada benzetilmektedir:

“Acaba ne umuyor böyle gevezelikte?

Şimdi, ayaklarımla öpüşen bu eşikte,

Bilmiyor mu kaç âşık kırdı gitarasını?” (Ali, 2016: 65)

Yat ve Uyu şiirinde şair karanlık ve uzun kış gecelerinde sevgilinin hayaliyle yanıp tutuşmakta olan bir âşıtır:

"Yine seni düşünmekle geçer zamanım...

Bu kimsesiz... Bu mahzun kış gecelerinde...” (Ali, 2016: 70)

Adres $\mid$ Address

RumeliDE Dil ve Edebiyat Araştırmaları Dergisi $\quad$ RumeliDE Journal of Language and Literature Studies

Osmanağa Mahallesi, Mürver Çiçeği Sokak, No:14/8 Osmanağa Mahallesi, Mürver Çiçeği Sokak, No:14/8

Kadıköy - İSTANBUL / TÜRKIYE 34714 Kadıköy - ISTANBUL / TURKEY 34714

e-posta: editor@rum

tel: +90 $5057958124,+902167730616$

e-mail: editor@rumelide.com

phone: +90 505 7958124, +90 2167730616 
Çakır adlı şiirde "köyün bir tanecik orospusu" (Ali, 2016: 88) şeklinde nitelenen Çakır, mavi gözleriyle insanı büyüleyen bir güzelliktedir. Herkesi eğlendirmesine ve her mecliste aranmasına rağmen birçok taze gelini kocasından etmiştir. Çakır bu durumdan memnun sayılmamalıdır; çünkü o da incecik bıyıklı yavuklusunu cephede kaybetmiş biridir. "O zaman gözünün önüne gelen / Cepheden şehitlik alıp yükselen / İncecik bıyıklı bir yavukludur...” (Ali, 2016: 89)

"Öteki Şiirler" adlı kısmın ilki olan Şarkı adlı şiirde şairin kalender ve rindane bir yapı içinde olduğu söylenebilir. Bu şiirinde sevgiliye pek çok kez "güzelim” şeklinde hitap eden Sabahattin Ali’nin ruhunun elemlerinden kurtulmak istediği görülmektedir:

"Uçsun güzelim aşkımızın kâmı udundan

Aksın güzelim ruhumun âlâmı udundan” (Ali, 2016: 101)

Aşk Başlangıcı adlı şiirde şairin, hissettiği bir aşkın başlangıç aşamasında yaptığı "Kalbimde sizin için /Parlayan için için / Sakın bir aşk olmasın?” (Ali, 2016: 103) gibi sorgulamalar söz konusudur. Ne Kazandık? adlı şiirde ise reddedileceğini bilmesine rağmen aşkından vazgeçemeyen bir âşığın kendini sorgulaması görülmektedir:

\author{
"Daima sizi sandık \\ İlâhe güzellikte! \\ Acaba ne kazandık \\ Gönlümüzü verdik de?..” (Ali, 2016: 109)
}

Sevgili, Acaba ve Gecenin Kemanı adlı şiirlerde âşıklardan âdeta intikam alan ve âşıklara türlü ayrılık acıları yaşatan zalim bir kişidir. Fakat bu yaptıklarıyla âşıkların gözünden giderek düşmektedir. Öyle ki kalp parçalayan bu sevgiliyi şair de yanında istemez olmuştur:
"Elâ gözünden akan
Ateşli nazarların
Acaba acimadan
Kimi yakacak yarın?” (Ali, 2016: 106)
"Sen, ey karanlıklara
Hicran dağıtan kadın!
Git başka bir diyara!
Kalbimi parçaladın...” (Ali, 2016: 107)

Masal formunda yazılan “ ، “Öksüz Kız” ' Masal”nda, bir gece vakti kasırga çıkar. Gökyüzündeki ay böyle bir gecede öksüz bir kız görür ve ona âşık olur:

\author{
"Bazan kızın keyfi coşar: \\ Bakraçla göle koşar \\ Ve ayın çektiği çile \\ Biter... Coşkun bir sevinçle \\ Gülen yüzü bedirlenir...” (Ali, 2016: 113)
}

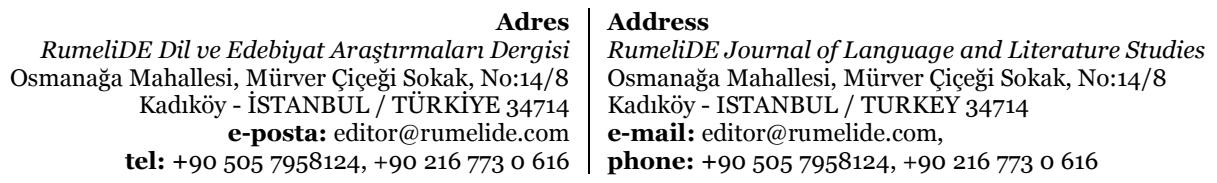


Kalbimde Aşkınız şiirinde bir âşığın, sevgilinin güzelliği karşısında büyülendiği ona yaptığı türlü övgülerden anlaşılmaktadır:

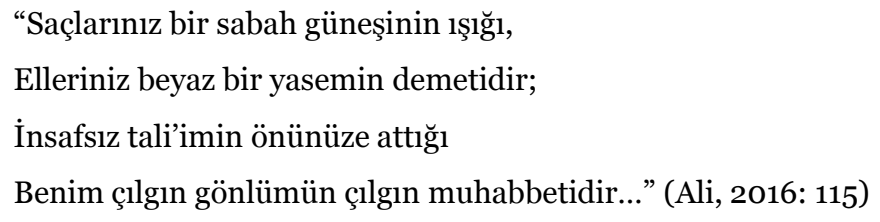

Şairin Der Vasf-ı Yâran-ı Terkîb-i Bend başlı̆̆ını taşıyan terkib-i bendinin başlangıcı olan "Rubâ'i”" kısmında dert içinde olduğu, bu dertlerin ve sevgilinin hatırasının âşı̆̆ın gönlünde nice coşkunluklar eylediği ifade edilmektedir. "Derdin beni âmâde-i nûş eyler yâr" (Ali, 2016: 128) dizesi bunu göstermektedir. Aynı şiirin "Nâhid" adlı bölümünde ise sevgili, âşığın aşkını kabul etmemekte, âşık da ona "Mâdem ki mey-i aşkı kâbul etmeyecekdin / Niçün kadeh-i kalbi şikest eyledin ey yâr" (Ali, 2016: 131) diye sormaktadır.

Terkib-i Bend'den sonra gelen Mesnevi başlıklı şiirde âşı̆̆ın sevgiliye seslenişleri görülür. İnsafsız sevgili, bu şiirde de âşı̆̆ı reddetmekte ve âşık da bu durumdan şikâyet etmektedir. Âşık, sevgiliden merakla aşk mektupları göndermesini ummakta iken sevgili önce âşığı bekletip daha sonra da latife ve bahanelerle dolu yazılar göndermektedir. Şiirin ilerleyen kısımlarında âşık, dostlarına "Sevgiliden bana bir selam var mı?” diye sorar. Onun hayaliyle fena hâllere düşen âşık, bu durumdan dolayı dostlarına "Sevdâ-zede oldu kalb-i zârım / Şerh et ona hal-i bî-kararım" (Ali, 2016: 148) diyerek dert yanmaktadır.

Şarkı (I) adlı şiirde “ (...) / Bizden kaçıp da elleri yâr eylesen de sen / Hem-bezm-i aşkın olmağa âr eylesen de sen / Bir gün gelir ki sabrile bendeyleriz seni” (Ali, 2016: 151) " dizeleriyle âşık tarafından sabırla beklenen bir sevgiliden söz edilmektedir. Şarkı (II) adlı şiirde şairin unutulmaz aşkı Nahit Hanım'ın adı geçmektedir. Nahit Hanım'ı her hatırladığında yazarın yüreği âdeta bayram yerine dönmektedir:

"Her ne dem manzûrum ol Nâhîd olur

Bezm-gâh-ı dilde yevm-i îd olur” (Ali, 2016: 152)

Şarkı (III) şiirinde sevgili, şaire yabancılaşmış bir durumdadır. Bu yabancılaşma şair için akıl işi değildir. Sevgilinin bu hâline anlam verememektedir. Şaire göre sevgili ancak zekâsını kaybederse kendisinden yüz çevirebilir:

"Hicâb eder gönül artık bu ibtilâsından

Ne cilvedir ki bu yârım yabancılaşmıştır” (Ali, 2016: 153)

Şarkı (IV) adlı şiirde ise âşık suya düşen mehtaba baktıkça ve girdaplar oluşturan suyu seyrettikçe hayatını ve sevgiliyi hatırlamaktadır.

"Geçer pîş-i hayâlimden hayâtım âba baktıkça

Seni yâd eylerim âba düşen mehtâba baktıkça” (Ali, 2016: 154)

b) Yüzeysel aşk: Bütün İnsanlara adlı şiirde, şairin inanç bağlamında zayıfladığını görmek mümkündür. Şair, özellikle Nahit Hanım’a olan romantik aşkının karşılıksız kalması sonucu bu şiiri yazmıştır:

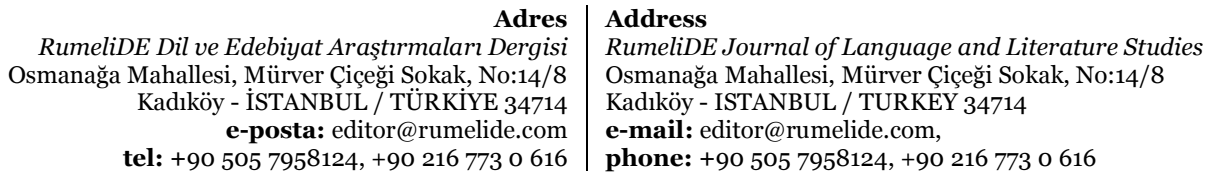




\author{
"Korkutmaz beni ölüm, \\ Bir şeytan kadar hürüm. \\ Süremez bende hüküm \\ Ne Allah, ne de Nahit..." (Ali, 2016: 69)
}

Yaşadığı aşk acısını genelleyen ve bütün insanlara karşı sevgisini ve güvenini kaybeden şair, Firar adlı şiirinde bir inziva hazırlığ

"Anladım insanlardan geldiğini kederin;
Uzak, herkesten uzak bir hayat süreceğim.
Benim bu inzivama taarruz edenlerin,

Yüzüne hakaretle, kinle tüküreceğim!..” (Ali, 2016: 68)

Firar şiiri geneli itibarıyla yüzeysel aşk kategorisindedir. Bu sebeple bu kategoriye dâhil edilmiştir; ancak şiirdeki "Kadınlar bana yalnız soğuk bir deri verdi." dizesi, aşkın şehevî ihtiras kategorisine uygun bir dizedir.

c) Şehevî ihtiras: Şair, Firar şiirindeki dizenin yanı sıra Kudurmak adlı şiirinde de aşka tensel olarak yaklaşır. "Etini bir canavar gibi ısıracağım” (Ali, 2016: 67) dizesi bu şiirdeki aşkın şehevi ihtiras kategorisinde olduğunu gösterir. Bu şiir dışında sevgili, onun için bir arzu malzemesi değil, âdeta manevî bir varlıktır. Sevgili fiziksel olarak değilse de hayalî olarak her zaman onun yanındadır.

d) Yüceltilmiş aşk: Şair, âşı olduğu kadınları saf ve temiz duygularla sever. Ebedî adlı şiirde "Taşlar bile sarsılır duyduklarımı yazsam / Ah kardeşim!.. Ben seni hiçbir şey yapamazsam / Ebedî yapacağım!.. Ebedî yapacağım!..” (Ali, 2016: 72) demesi, bu şiiri yüceltilmiş aşk kategorisine yaklaştırır. Ayrıca bu dizeler, şairin aşka ve âşık olduğu kadınlara karşı derin bir saygı beslediğinin göstergesidir. Eşi Aliye Hanım da bu kadınlardan biridir. Esra Yıldız, "Sabahattin Ali'nin Eserlerinde Aşk” adlı yüksek lisans tezinde şairin, eşine olan duyguları hakkında:

\begin{abstract}
"Duygularını bu denli yoğun yaşayan Sabahattin Ali, Aliye hanım’ hayatının merkez noktası yapar, kendisinin diğer yanının Aliye Hanım olduğunu söyler, sevdiği kadın için fedakarlık noktasında sınır tanımaz, Onu herkesten ayrı bir konumda tutar, bahsi geçen durum aşkın yüceltilmesi noktasında son derece önemlidir, sevdiği kadına hitap etmesi ise hep sahiplenme şeklinde görülür, ‘Sevgili Aliye'm...,Benim Aliye’m’ diyerek sevdiği kadını sahiplenir.” (Yıldız, 2017: 19).
\end{abstract}

demektedir. Şair, Aliye Hanım ile evlendikten sonra aşk temli bir şiir yayımlamamıştır.

\title{
Dil ve üslup
}

Nurullah Çetin’in, “Şiir Çözümleme Yöntemi”ndeki dil kategorilerine göre incelendiğinde aşk temli şiirlerde bir yazım sapması olmadığı görülecektir.5 Ses sapması açısından Servi şiirinde "burda" (Ali, 2016: 32) ve “ “Öksüz Kız” ' Masal şiirinde "yapyalnı" (Ali, 2016: 111) kelimeleri ünlü düşmesine örnek olarak gösterilebilir. Ağlayı Ağlayı şiirinde her dörtlüğün son dizesinde yer verilen "ağlayı ağlayı" ikilemesinde (Ali, 2016: 49), Kızkaçıran şiirinde "candarmalardan" (Ali, 2016: 42), Mayıs şiirinde "içerim" (Ali, 2016: 43), Hey şiirinde "Kaygusuz" ve "yundum" (Ali, 2016: 44), Uzakta şiirinde "gülmeğe" (Ali, 2016: 51), Eskisi Gibi şiirinde "kardaşım” (Ali 2016: 52), Son Mektup şiirinde "yaşamağa” (Ali, 2016: 57), Kurbağanın Serenadı şiirinde "çalmağa” (Ali, 2016: 65), Kıyamadığım

5 Yazım sapmasından kasıt; özel isimlerin ya da dizelerin ilk harflerinin küçük yazılması, kelimeleri bile bile yanlış yazmak, noktalama işareti gereken yerlerde işaret kullanmamak ya da yanlış işaret kullanmak gibi hatalardır.

Adres | Address

RumeliDE Dil ve Edebiyat Araşttrmaları Dergisi $\quad$ RumeliDE Journal of Language and Literature Studies Osmanağa Mahallesi, Mürver Çiçeği Sokak, No:14/8 $\quad$ Osmanağa Mahallesi, Mürver Çiçeği Sokak, No:14/8

Kadıköy - İSTANBUL / TÜRKIYE 34714 Kadıköy - ISTANBUL / TURKEY 34714 e-posta: editor@rumelide.com

e-mail: editor@rumelide.com

tel: +90 505 7958124, +90 2167730616 phone: +90 505 7958124, +90 2167730616 
adlı şiirde "öpmeğe" (Ali, 2016: 47) ve Kudurmak şiirinde "içerim" (Ali, 2016: 67) kelimelerinde de ağız özellikleri görülmektedir. Böylece şair, gündelik konuşma dili ve ağız söyleyişleriyle şiirlerine canlılık ve tabiilik kazandırmak istemiştir.

Argo ve küfür kullanımı, Firar şiirinde "tüküreceğim" (Ali, 2016: 68), Bütün İnsanlara şiirinde "it" (Ali, 2016: 69), Sevdasız şiirinde "yuf" (Ali, 2016: 91), Hayat (Bedbin) şiirinde "gebersem" ve "sersem" (Ali, 2016: 98), Çakır şiirinde ise “orospusudur.” (Ali, 2016: 88) kelimesinde görülmektedir.

İfade sapmalarından biri olan deyimleri bilinenden farklı kullanma, Öyle Günler Gördüm ki... şiirinde, "Sırtımı sıvazladı, bana öğüt savurdu." (Ali, 2016: 61) dizesinde görülmektedir. Aslı "öğüt vermek” olan deyim, bu dizede "öğüt savurmak" biçimine dönüştürülmüştür.

Sabahattin Ali'nin aşk temli şiirlerinde, dil bilgisi bakımından; edatların farklı kullanımı, ikilemeleri ters çevirme, alışılmamış tamlamalar kurma, geçişsiz fiili nesne ile kullanma gibi durumlara rastlanmaz. Kelimelere yanlış ek getirmeye örnek olarak Ebedî şiirindeki "inledimdi” (Ali, 2016: 72) kelimesi gösterilebilir. Şiirlerde ödünç metinlere müdahale görülmez.

Şiirler konuşma dili açısından incelendiğinde, ünlem kullanımına Servi şiirinde "Hey rahat isteyen sersem!” (Ali, 2016: 32), Hey şiirinde "Divânelere döndüm hey!” (Ali, 2016: 44), Kurbağanın Serenadı şiirinde "Onu çiğne sevgilim! Onu çiğne sevgilim!” (Ali, 2016: 65), ikileme kullanımına “ “ “Öksüz Kız” , Masalı" şiirinde "Yavaş yavaş yükseldi, gökler alçald,," (Ali, 2016: 112), Kıyamadığım adlı şiirde "Hey bir zaman bakıp bakıp" (Ali, 2016: 47), Ağlayı Ağlayı şiirinde "Öldüm ağlayı ağlayı.” (Ali, 2016: 49), samimi hitap kullanımına “ “ "Öksüz Kız” 'Masal»” şiirinde "Çıldırdın mı kız?” (Ali, 2016: 111), Eskisi Gibi adlı şiirde "Gel sevgilim, gel kardaşım," (Ali, 2016: 52), deyim kullanımına Hapishane Şarkısı IV şiirinde "Ağlayıp içimi döksem..." (Ali, 2016: 39), Firar şiirinde "Ne manasız şeylere meğer bel bağlamışım;" (Ali, 2016: 68) ve Unutamadım adlı şiirde "Gönlümü sana vermişim.” (Ali, 2016: 48) dizeleri örnek olarak gösterilebilir. Şiirlerde atasözü kullanımına ise rastlanmamıştır.

Şiirlerde tabii, canlı ve akıcı söyleyiş tercih edilmiştir. Eksiltili ifade çeşitlerinden düşünce çizgisi ve kelime eksikliği aşk temli şiirlerde görülmez iken ek eksikliği Bir Macera şiirinde "Fakat şimdi saçlarım beyaz[ladı], yüzüm buruştu;" (Ali, 2016: 116) dizesinde görülmektedir. Şair, özel adların çağrışımlarından yararlanma hususunda ise Bütün İnsanlara adlı şiirde "Süremez bende hüküm / Ne Allah, ne de Nahit...” (Ali, 2016: 69) diyerek Allah’ın hükmünün kendisi için önemli olmadığını, kendini bu hüküm altında hissetmediğini ve sevdiği kadın olan Nahit Hanım'a artık mecbur olmadığını ifade etmektedir. Bu şiirler kelime yoğunluğu bakımından incelendiğinde şairin daha çok; "ben”, "sen”, "gönül”, "kalp”, "yâr”, "sevgili” ve "aşk” gibi kelimeleri tercih ettiği görülür (Güngör, 2019: 181).

Şair, aşk temli şiirlerinde çoğunlukla lirik üslubu tercih etmiştir. (Kıyamadığım, Yetmez mi?, Ayırdılar, Unutamadım, A ğlayı A ğlayı...)

*Lirik üsluba Unutamadım şiirindeki: "Bahtım lûtfuna ermişim. /Gönlümü sana vermişim. / Meğer ne çok severmişim, / Yâr, seni unutamadım.” (Ali, 2016: 48) ve Ayırdılar şiirindeki "Şaşırdım aşka düştükçe, / Yere vuruldum coştukça; / Doğrulup sana koştukça / Seni benden ayırdılar.” (Ali, 2016: 46) dizeleri örnek olarak verilebilir. Bunun dışında

*Övgü (Ne Kazandık?, Kalbimde Aşkınız), Ne Kazandık? adlı şiirdeki "Siz daha sedefinde / Bâkir bir incisiniz; / Belki birincisiniz / Âşılar hedefinde!” (Ali, 2016: 109), 
*Soru sorma yoluyla şaşırtma (İstek, Yetmez mi?, Bir Doğum Günü İçin, Kurbağanın Serenad, Hayat (Bedbin), Ne Kazandik?), Yetmez mi? şiirindeki “Aşk seni harab etmez mi? / Takatını tüketmez mi? /Sendeki ateş bitmez mi? / Yetmez mi gönül, yetmez mi?” (Ali, 2016: 45),

*Karşıtllı yoluyla şaşırtma (Hapishane Şarkısı IV, Hey, Çocuklar Gibi, Koşma, Aşk Başlangıcı), Çocuklar Gibi adlı şiirdeki “Bazı nur içinde, bazı sisteydim,” (Ali, 2016: 54),

*Tasvir gibi üslup özellikleri (Mayıs, Uzakta, Çakır) Çakır şiirinin "Altın saçlarını sıkıca tarar, / Sonra iki örgü yana bırakır; / Ayağında pembe dallı mor şalvar, / Taze gelin gibi süzülür Çakır...” (Ali, 2016: 88) dizeleriyle örneklenebilir.

Ayrıca yalın söyleyiş -Terkib-i Bend, Mesnevî, Şarkı I, Şarkı II, Şarkı III ve Şarkı IV adlı şiirler hariçşairin şiirlerinde tercih ettiği üslup özelliklerindendir.

\section{Sonuç}

Sabahattin Ali; hayatında aşka kıymet vermiş, ondan kuvvet almış, âşı olduğu kadınları değerli görüp onlara saygı duymuş bir şairimizdir. Aşkı bu derece önemseyen yazarın, şiirlerinde en çok aşk temine yer vermiş olması tabiidir. 73 şiirden 51'inde yazarın bir şekilde aşkın veya yârin sözünü ettiği görülür. Bu şiirlerin 43'ü romantik aşk kategorisinde, 2'si yüzeysel aşk kategorisinde, birer tanesi de şehevî ihtiras ve yüceltilmiş aşk kategorilerindedir. Ayrıca bazı şiirler iki kategorinin de özelliklerini gösteren dizelere sahiptir. Dört şiirde ise aşkın veya yârin sözü edilmesine rağmen bu şiirlerin herhangi bir aşk kategorisinde düşünülmemesi gerektiği sonucuna varılmıştır.

Sabahattin Ali'nin, aşk temli şiirlerinin çoğunda aşkı ve âşık olduğu kadınları idealize ettiği sonucuna varılabilir. Şaire göre dünyada sevda ateşi ile yanmamış bir kalp yoktur. Elbette her kalp vuslat sevincine ermemiştir; ancak yine de bu, âşı olmaya engel değildir. Hatta ona göre vuslat sevincine ermeyen, aşk yolunda acı çeken kişi gerçek bir âşıktır. Sevgili ise âşı̆̆ın hayatına devam etmesini sağlayan, onu hayata karşı güçlü kılan kişidir. Âşık, dünyadaki varlığını ona borçludur. Sevgili onun için bir ışıktır, inanç kaynağıdır, dert ortağıdır. Âşık; onu nazı ve işvesiyle, her türlü haliyle sevmiş ve benimsemiştir. Ona duyduğu aşkın bir hududu yoktur. Yaşamaya hevesi kalmasa da, divânelere dönse de sevgiliden vazgeçmesi imkânsızdır. Araya girip entrikalar çeviren fesatların varlı̆̆ına ve kendisinden yana olmayan bahtına rağmen âdeta büyülenmiş gibi ona bağlıdır. Bazı şiirlerde ise sevgiliye kavuşamamanın neden olduğu özlem ya da onun başkalarını tercih etmesi gibi durumlar karşısında âşı̆̆ın sabrını, dengesini ve inancını yitirdiği sonucuna varılabilir. Âşık, bu durumda beklemeyi bırakır ve karamsar bir kişi hâline gelir. Bu zamanlarda sevgili âşığın gözünde değer kaybeder. Âşık, sevgili için katlandığı acıları düşünerek ne kazandığını sorgular. Ümitsizlik her yanını kaplasa da onu hâlâ sevmekte ve ondan vazgeçememektedir.

Dil ve üslup açısından incelendiğinde şiirlerin yalın, tabii ve canlı bir dille yazıldığı, az sayıda ağız kullanımına yer verildiği sonucuna varılır. Argo ve küfür kullanımına nadiren de olsa rastlanır. Şiirlerde ünlem, ikileme ve deyimler de şairin söyleyişindeki tabiilik ve canlılığı kuvvetlendiren unsurlar olarak dikkat çeker. Kelime kadrosu bakımından genellikle aşk temli şiirlerde tercih edilen kelimelerin seçildiği görülür.

Sonuç olarak Sabahattin Ali’nin içinde aşk duygusunu barındıran şiirlerinin, onun hayat karşısındaki savunması olduğu söylenebilir.

\begin{tabular}{|c|c|}
\hline & \\
\hline eliDE Dil ve Edebiyat Araşstırmaları De & Eournal of Language and Literature Studies \\
\hline 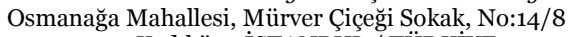 & Mahallesi, Mürver Çiçeği Sokak, No:14/8 \\
\hline Kadıköy - İSTANBUL / & ISTANBUL / TURKEY 34714 \\
\hline $\begin{array}{r}\text { e-posta: editor@rumelide.com } \\
\text { tel: +90 505 7958124, +90 } 2167730616\end{array}$ & $\begin{array}{l}\text { e-mail: editor@rumelide.com, } \\
\text { phone: +90 505 7958124, +90 } 216773 \text { o } 616\end{array}$ \\
\hline
\end{tabular}




\section{Kaynakça}

Aksu, Sevinç Türkmen (2017). "Hakikat Sevgisi ve Hakikat Arzusu Olarak Felsefe: Platon ve Spinoza", Felsefe ve Sosyal Bilimler Dergisi. (S.24): 277-294.

Aytaç, Aslıhan (2018). "Sabahattin Ali Şiirlerinde Trajik Yazgı", HECE, Susturulamayan Ses Sabahattin Ali Özel Sayısı. Özel Sayı: 35, (S. 253): 776-784.

Biricik, İbrahim (2017). "Sabahattin Ali’nin Eserlerinin Kaynakları Roman, Hikâye ve Şiirlerinde Biyografik Unsurlar” Mecmua Uluslararast Sosyal Bilimler Dergisi. (3), 55-59.

Çetin, Nurullah (2008). Şiir Çözümleme Yöntemi. Ankara: Öncü Kitap.

Devellioğlu, Ferit (2002). Osmanlıca - Türkçe Ansiklopedik Lûgat. Ankara: Aydın Kitabevi.

Ergin, Özgen, “O, -Sabahattin Ali-” Gerçek Edebiyat 2016. https://gercekedebiyat.com/haber-detay/osabahattin-ali---ozgen-ergin/2085 [Erişim tarihi: 27.12.2020].

Güngör, Bilgin (2019). "Bir Poetikanın İstatistiği: Sabahattin Ali’nin Şiirlerini Kelimeler Işı̆̆ında Yeniden Düşünmek", Kültür Araştırmaları Dergisi, C.1, S.2, s. 174-182.

İmam-ı Muhammed Gazâli (2016). Mükâşefetü’l-Kulûb (Kalplerin Keşi). Çev. Salih Uçan. İstanbul: Çelik.

Korkmaz, Ramazan (1991). Sabahattin Ali -İnsan ve Eser-. (Doktora Tezi), Elazığ: Firat Üniversitesi Sosyal Bilimler Enstitüsü.

Korucu, Ayşe Arzu (2019). "Freudyen ve Jungiyen Yaklaşımlarla Anne Olgusu”, Atatürk Üniversitesi Sosyal Bilimler Enstitüsü Dergisi. 23(1), 133-143.

Sabahattin Ali (2016). Sabahattin Ali Bütün Şïrleri. Haz. Atilla Özkırımlı, İstanbul: Yapı Kredi.

Sabahattin Ali (2018). Canım Aliye, Ruhum Filiz. Haz. Sevengül Sönmez, İstanbul: Yapı Kredi.

Sağlam, Mehmed Halil (2020). "Sabahattin Ali’nin Şiirlerinde Dağ İmgesi”, Sosyal ve Beşeri Bilimler Araştırmaları Dergisi. 21(46), 86-101.

Şemseddin Sami (2018). Kâmûs-ı Türkî (Latin Harfleriyle). Haz. Raşit Gündoğdu, Niyazi Adıgüzel, Ebul Faruk Önal, İstanbul: İdeal Kültür.

TDK (Türk Dil Kurumu) (1988). Türkçe Sözlük I, Ankara: Türk Dil Kurumu.

Uludağ, Süleyman (1991). “Aşk”. İslâm Ansiklopedisi. C.4. İstanbul: Türkiye Diyanet Vakfı Yay. s.11-21.

Yıldız, Esra (2017). Sabahattin Ali’nin Eserlerinde Aşk. (Yüksek Lisans Tezi), İstanbul: Marmara Üniversitesi, Türkiyat Araştırmaları Enstitüsü.

RumeliDE Dil ve Edebiyat Araşttrmalar Dergisi Osmanağa Mahallesi, Mürver Çiçeği Sokak, No:14/8 Kadıköy - İSTANBUL / TÜRKIYE 34714 e-posta: editor@rumelide.com tel: +90 505 7958124, +90 2167730616
Address

RumeliDE Journal of Language and Literature Studies

Osmanağa Mahallesi, Mürver Çiçeği Sokak, No:14/8

Kadıköy - ISTANBUL / TURKEY 34714

e-mail: editor@rumelide.com,

phone: +90 505 7958124, +90 2167730616 